\title{
VITAMIN E AS AN ANTIOXIDANT
}

\section{E VITAMINIININ ANTIOKSIDAAN ROLÜ}

\author{
Bilgehan DOĞRU PEKIINER \\ Ankara University, Faculty of Pharmacy, Department of Biochemistry \\ 06100 Tandoğan, Ankara, TURKEY
}

\begin{abstract}
Antioxidant defences that protect the body from free-radical damage include the enzymes and the antioxidant vitamins. Free radicals are generated endogenously under physiological and pathological conditions but also upon exposure to exogenous challenge. Vitamin $E$ is well accepted as nature's most effective lipid-soluble, chain-breaking antioxidant, protecting cell membranes from free-radical mediated peroxidative damage. Free-radical mediated pathology has been implicated in the development of degenerative diseases, conditions and also aging process. In animals a-tocopherol (the most active form of vitamin E) is membrane bound which was suggested to have a dual role where the phenolic nucleus acts as an antioxidant on the surface of the membrane while the side chain stabilizes the membrane with the lateral methyl groups fitting into gaps caused by cis double bonds in the fatty acids. Thus the molecular mechanism of vitamin $E$ is mediated by the antioxidant function or its membrane stabilizing effect. This paper reviewes the current research on the protective role of vitamin $E$ as an antioxidant.
\end{abstract}

Key words: $a$ - tocopherol, vitamin E, antioxidant.

\section{ÖZET}

Viicudu serbest radikal hasarından koruyan antioksidan savunma enzimler ve antioksidan vitaminler< icermektedir. Serbest radikaller fizyolojik ve patolojik durumlarda ve ayrica diş kaynaklara maruziyetle uretilmektedir. E vitamini hücre membranlarini serbest radikal aracılı peroksidatif hasardan koruyarak doğanın en etkin lipidde-çözünen zincir-kırıcı antioksidani olarak kabul edilmiştir. Serbest radikal aracılı patoloji dejeneratif durumlar, hastalıklar ve ayrica yaşlılık gelişimine dahil edilmektedir. Hayvanlarda $E$ vitamininin en etkin sekli olan a-tokoferol membrana bağlıdır. a-Tokoferol için cifte rol ileri sürülmüş̧ür kifenolik çekirdeği membran yüzeyinde antioksidan olarak etki ederken, yan zincirindeki metil grupları, membran yă̆ asitlerinin çifte bă̆larınca oluşturulmuş ceplere girerek membrani stabilize etmektedir. Böylece E vitamininin moleküler mekanizmasına antioksidan etkisi ya da membrane stabilize edici etkisi aracllk etmektedir. Bu makalede $E$ vitamininin antioksidan koruyucu rolü üzerinde hali hazırdaki araştırmalar derlenmiştir.

Anahtar kelimeler: a- Tokoferol, E vitamini, antioksidan. 


\section{INTRODUCTION}

\section{The discovery of vitamin $\mathrm{E}$}

Almost 60 years ago, the nutritional essentiality of vitamin $\mathrm{E}$ was recognised for the first time. In 1922, rats given a semi-purified diet containing the then known vitamins, failed to reproduce (1). Two years later an, as yet undescribed dietary factor, was demonstrated and the inadequacy of this factor in the diet resulted in foetal resorption. Wheat germ oil and lettuce were identified as good sources of this factor which was recognized as a vitamin and called vitamin E. In 1931 Pappenheimer and Goettsch (2) described nutritional encephalomalacia (a central nervous system defect, clinically characterized by ataxia, spasms and paralysis) in chicks given semi-purified diets. In 1936 Evans et al (3), reported the isolation of a fat-soluble alcohol which had vitamin E activity and named it oc-tocopherol. The following year $\mid 3-$ and $y-$ tocopherols were isolated from vegetable oils (4). Later, another substance named 8-tocopherol was isolated from soybean oil .

Since these discoveries numerous investigators, using several species, have demonstrated nutritionally significant interrelationships between vitamin E and several dietary components (5, $6)$.

\section{Structure of vitamin $\mathbf{E}$}

Tocopherols are derivatives of tocol. The multiple nature of tocopherols isolated from plant oils suggested that they were analogues of oc-tocopherol which differed only in the number and arrangement of the methyl groups. The term vitamin $\mathrm{E}$ is used as a generic description for all tocol and tocotrienol derivatives qualitatively exhibiting the biological activity of octocopherol. The natural stereo-isomer of oc-tocopherol is (2R, $\left.4 \mathrm{R}^{\prime}, 8^{\prime} \mathrm{R}\right)$ - oc-tocopherol or RRRoc-tocopherol.

Later it was shown that some of these substances contained three double bonds in the side chain (7), and the name tocotrienol was proposed for them. What is referred to as vitamin $\mathrm{E}$ is a mixture of at least eight related substances (oc-,|3-, y-, 6- tocopherols and a-, (3-, y-, 8tocotrienols) (8). The structures of natural tocopherols and tocotrienols are shown below. 


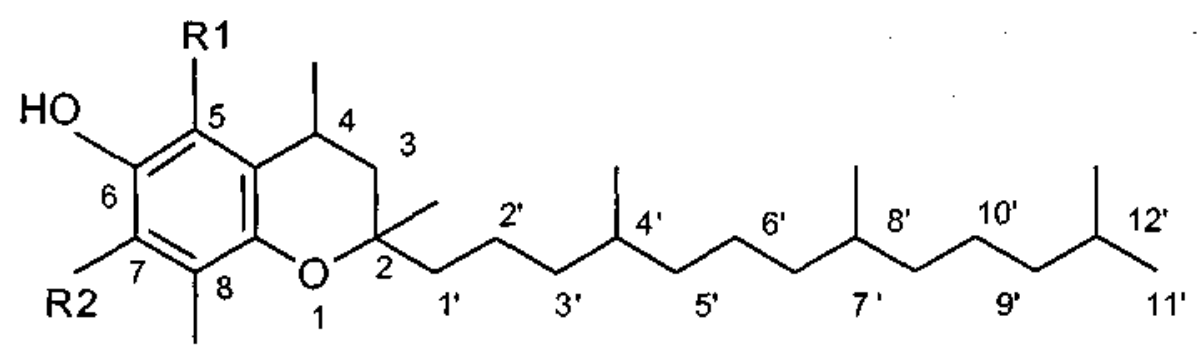

R3

$\begin{array}{lccc}\alpha \text {-tocopherol } & \underline{\mathbf{R}}_{1} & \mathbf{R}_{2} & \mathbf{R}_{3} \\ \beta \text {-tocopherol } & \mathbf{C H}_{3} & \mathbf{H} & \mathbf{C H}_{3} \\ \gamma \text {-tocopherol } & \mathbf{H} & \mathbf{C H}_{3} & \mathbf{C H}_{3} \\ \delta \text {-tocopherol } & \mathbf{H} & \mathbf{H} & \mathbf{C H}_{3}\end{array}$

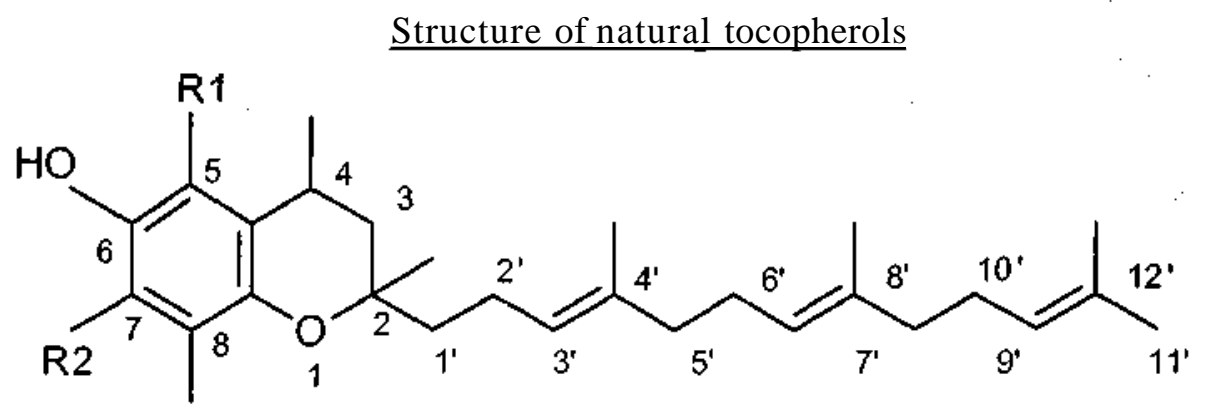

R3

\begin{tabular}{|c|c|c|c|}
\hline & $\underline{\mathrm{R}_{1}}$ & $\underline{\mathrm{R}_{2}}$ & $\underline{\mathrm{R}_{3}}$ \\
\hline$\alpha$-tocotrienol & $\mathrm{CH}_{3}$ & $\mathrm{CH}_{3}$ & $\mathrm{CH}_{3}$ \\
\hline$\beta$-tocotrienol & $\mathrm{CH}_{3}$ & H & $\mathrm{CH}_{3}$ \\
\hline$\gamma$-tocotrienol & H & $\mathrm{CH}_{3}$ & $\mathrm{CH}_{3}$ \\
\hline$\delta$-tocotrienol & H & H & $\mathrm{CH}_{3}$ \\
\hline
\end{tabular}

$\underline{\text { Structure of natural tocotrienols }}$

Tocopherols are widely distributed throughout the plant kingdom, a-tocopherol is the most widespread, being found essentially in the chloroplast. Other tocopherols are located outside the chloroplast The subcellular location of the non-oc-tocopherols is not fully understood. Newton and Pennock (9) worked with green leaves and suggested that y-tocopherol was located outside the chloroplast. Other workers examining plastid fractions from green leaves, have found small amounts of (3- and $y$-tocopherols (10) and 5-tocopherolquinone (11). In the brown algae Fucus spiralis (3-, y- and S-tocopherols are located outside the plastid (9). No 
tocopherols have been found in the nucleus, cell wall or ribosomes of the cell . 8 -Tocopherol is found in the microsomal and soluble fractions whilst y-tocopherol is associated with the cell fraction containing organelles such as mitochondria and golgi.

\section{BIOPOTENCY}

The biological activity of the tocopherols varies greatly and this variation is only partly correlated with the antioxidant action (12-16). In 1937, Olcott and Emerson (17) showed that the three naturally occurring forms of vitamin E then known (a-, P- and y-tocopherols) were in vitro antioxidants, preventing the oxidation of lard. However, the antioxidant activity found was the reverse of that found for the biological activity; y-tocopherol was the most effective antioxidant, then $\mathrm{P}$ - and a- least effective whereas in vivo experiments found the activity to be in the order $\mathrm{a}>\mathrm{P}>\mathrm{y}$. The most biologically potent of the four tocopherols is a-tocopherol (1820). Diplock et al, showed that the higher biopotency of RRR-a-tocopherol was partly related to its increased uptake by the cells whereas all the other tocopherols had a lower uptake level and a lower biopotency than all rac- a-tocopherol. Although the uptake and biopotency of Ptocopherol was not significantly different than a-tocopherol, both paramerters for $y$ - and 8 tocopherol were lower (21).

Previous studies (22-23) have shown that -a-tocopherol has the highest biologic activity and it is generally accepted to be the most important antioxidant. However, recent studies have demonstrated that $\mathrm{y}$-tocopherol is a more effective free radical scavenger than -a-tocopherol (24-25). Several clinical trials have failed to demonstrate any beneficial effects of commercial a-tocopherol preparations in prevention of cardiovascular death, meanwhile tocopherols in the food seem to be beneficial. Liu et al (26) have shown that the mixed tocopherol preparation has a more potent protective effect than a-tocopherol alone in preventing lipid peroxidation. They found that 3- and 8-tocopherol in mixed tocopherol are taken up by erythrocytes more readily than a-tocopherol and the use of mixed tocopherol protects erythrocytes more efficiently from lipid peroxidation than a-tocopherol alone. This observation may explain why the administration of a-tocopherol in clinical trials have failed. Mixed tocopherols may thus be important in the suppression of free radical-induced lipid peroxidation.

Although it is generally accepted that the relative antioxidant activities of the tocopherols in vivo is in the order a $>\mathrm{P}>y>8(27-30)$ there appears a general confusion for their relative potency in vitro (31). The chemical structures of the tocopherols and tocotrienols gives a hydrogen donating power in the order a $>\mathrm{P}>y>8$ (32). This order of acivity was also observed in a homogenous solution in dichlorobenzene (31) but the order was reverse in fats, oils and lipoproteins in vitro (33-39). The reason for this reversed order is not yet clearly understood. However it is now realized that in vitro activities of tocopherols are not only dependent on their absolute chemical reactivities toward free radicals, but also on other possible 
side reactions. These side reactions, that are dramatically affected by tocopherol concentrations $(40,41,35)$, by light and temperature $(42,43)$, solvent $(44)$, type of substrate $(42,45,46)$ and by prooxidants and synergists in the system, may be highly propagative. Thus all the chemical and physical parameters of the system significantly affects the reaction mode of chromanols.

The presence of the phenolic hydroxyl in tocopherols and tocotrienols is critical for activity, but there is no agreement on its role. When the hydroxyl group is masked a total loss of activity is seen. On the other hand, replacement of the hydroxyl by an amino group or esterification of the hydroxyl have no significant effect on the activity (12). Probably esterified tocopherol is cleaved to the free phenol before absorption. It has been accepted that the phytyl side chain of vitamin $\mathrm{E}$ at the 2-position facilitates the incorporation and retention of vitamin $\mathrm{E}$ in biomembranes $(47,48)$. In order to understand the role of phytyl side chain of vitamin $\mathrm{E}$ in the biological membranes effects of vitamin $\mathrm{E}$ ant its analogue 2,2,5,7,8-pentamethyl-6chromanol (PMC) (vitamin E without side chain) on the inhibition of the oxidation of methyl linoleate and soybean phosphatidylcholine in homogenous solution and in aqueous dispersion have been studied (47). These antioxidants showed similar antioxidative activities. It was concluded that the antioxidant activities of vitamin $\mathrm{E}$ and its analoque without the side chain were quite similar within liposomes, micelle and in homogenous solution whereas the phytyl side chain enhanced the retainment of vitamin E in liposomes (49) and suppress the transfer of vitamin $\mathrm{E}$ between liposomal membranes.

The presence of three methyl groups in the aromatic ring is required for the optimal activity. A sharp reduction in the activity takes place when a methyl group is lost. a-Tocopherol is shown to be the most active form of all tocopherols toward peroxyl radicals $(50,51)$ in the resorption gestation (52) and in the muscular dystrophy test (53). p-Tocopherol has 25-40\% and y-tocopherol has 8-19\% of a-tocopherol activity when measured by gestation resorption assay (52). Furthermore, they showed that synthetic 5,7 dimethyl tocol has $60 \%$ of the $a$ tocopherol activity which suggested that the presence of methyl groups in the positions ortho to the hydroxyl group is important for the biological activity of the tocopherol. They also showed that synthetic tocol, synthetic 5-methyl tocol and 7-methyl tocol had negligible activities. Among the various methods used to assess the biological activity of the different tocol derivatives, the most commonly accepted being the rat fetal resorption assay (54). Authors ascribed relative biopotencies of 100, 56, 16 and $0.5 \%$ to a-, (3-, $y$ - and 5- tocopherols respectively. Tocotrienols, generally show very low biological activity and only a -tocotrienol has a significant activity in the haemolysis test being about $25 \%$ of the activity of a -tocopherol (19). The overall activity of this family is only $16 \%$ that of tocopherols (54).

The results show that all three methyls are important for maximal activity. Since (3-, $y$ tocopherol and 5,7-dimethyl tocol all show some activity while 5-, 7- and 8- methyl tocols have negligible activity it can be seen that two methyls can endow some biological activity. Comparing the relative activities of the dimethyl tocols shown above it would appear that the 
importance of the three methyls is $5>7>8$. The relative biopotencies of tocopherols and tocotrienols are shown below (table 1).

Table 1 Relative biopotencies of tocopherols and tocotrienols (55)

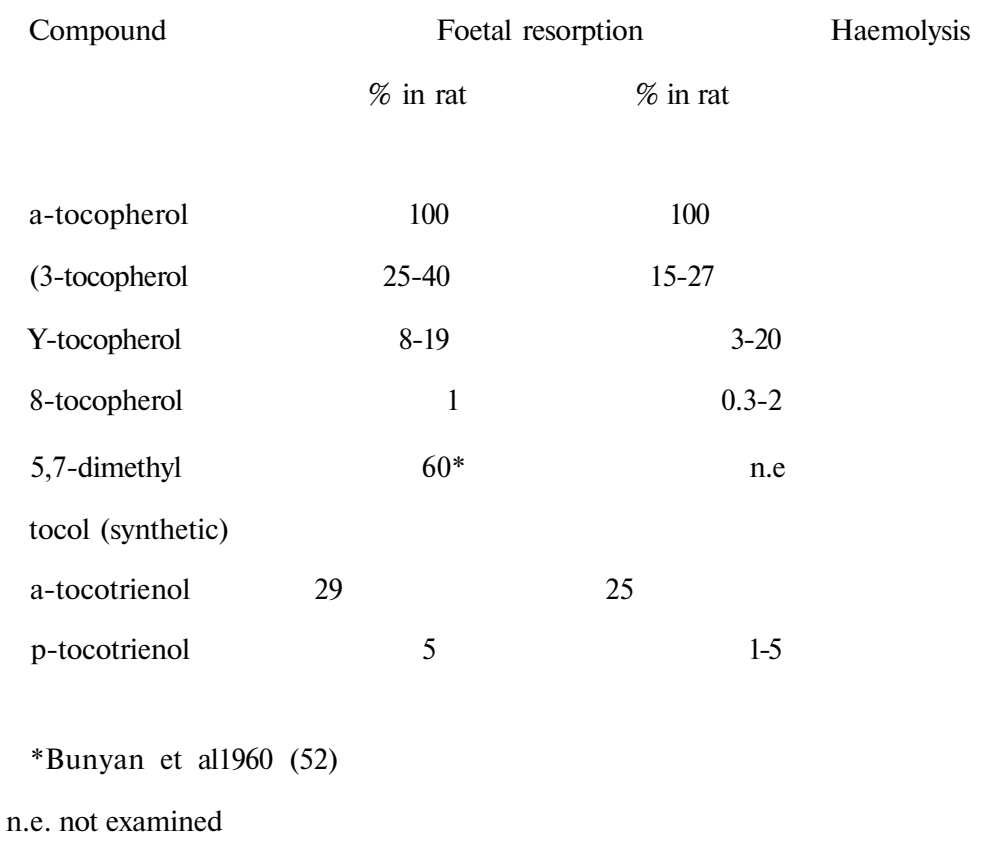

\section{Vitamin $\mathbf{E}$ in membranes}

Tocopherols have been shown to be very important components of biological membranes where they may act as antioxidants $(56,57)$ and play a role in membrane stabilization $(56-59)$.

Vitamin E is detected in most tissues and mainly in those membranes (60-65) with the highest PUFA concentrations (66-67). This is not only because a-tocopherol is lypophylic but also its 16-carbon phytol side chain provides the ability to form an integral part of the membrane. According to Diplock and Lucy's hypothesis (68), which was based on studies of molecular models, vitamin E may stabilize biological membranes by virtue of lipid- lipid interactions between its phytyl side chain and the fatty acyl chains of PUFA, particularly those derived from arachidonic acid (figure 1). It may thus exert its free-radical scavenging function towards peroxidizing PUFA. This was confirmed by Burton and Ingold (69) who demonstrated that removal of phytyl side chain did not diminish the in vitro antioxidant potential of octocopherol but completely destroyed its in vivo function, a-tocopherol becomes an integral part of the membrane exerting its free-radical quenching role. This concept unites the theory of Tappel (70) with that of Diplock and Lucy (68) who suggested that a-tocopherol acted by conferring stability on the membrane. Diplock and Lucy (68) suggested that antioxidant action is near the surface of the membrane. The methyl groups of the phytyl side chain fit into the the 
pockets created by cis double bonds and may facilitate the molecular packing within membranes, while the hydroxyl group of the chromanol ring and polar groups of phospholipid lie together at the membrane surface (55) (fig. 1). By this localisation vitamin E helps to maintain membrane integrity and permeability (71), thus controlling unspecifically the cellular metabolism and functioning of cells (72). The consequences of forming such a complex ie between vitamin E and PUPA are several. Firstly oxidative destruction of PUFA either in vivo $(73,74)$ or in vitro $(58,75,76)$ is inhibited. Secondly, the permeability of biological membranes containing high levels of PUFA, particularly arachidonic acid is reduced by the presence of Vitamin $E(49,77)$ that is the restriction of molecular mobility of the membrane lipid bilayer with vitamin E $(68,78)$. Thirdly, the complex stabilizes membrane-bound phospholipases (7981) and stabilizes the polypeptide chains of intrinsic proteins against the modifying effects of free fatty acids. Studies have demonstrated a stabilizing effect of cc-tocopherol against the damages caused by free acids $(57,79,81)$. This effect can either be due to the direct interaction of oc-tocopherol with $\mathrm{ca}^{2+}$-dependent ATPase or to its interaction with free fatty acid. It has been demonstrated that vitamin $\mathrm{E}$ can protect biological membranes against the damaging action of phospholipases as well as the phospholipid hydrolysis products by phospholipase A namely free fatty acids and lysophospholipids $(57,77,81,82$, ).

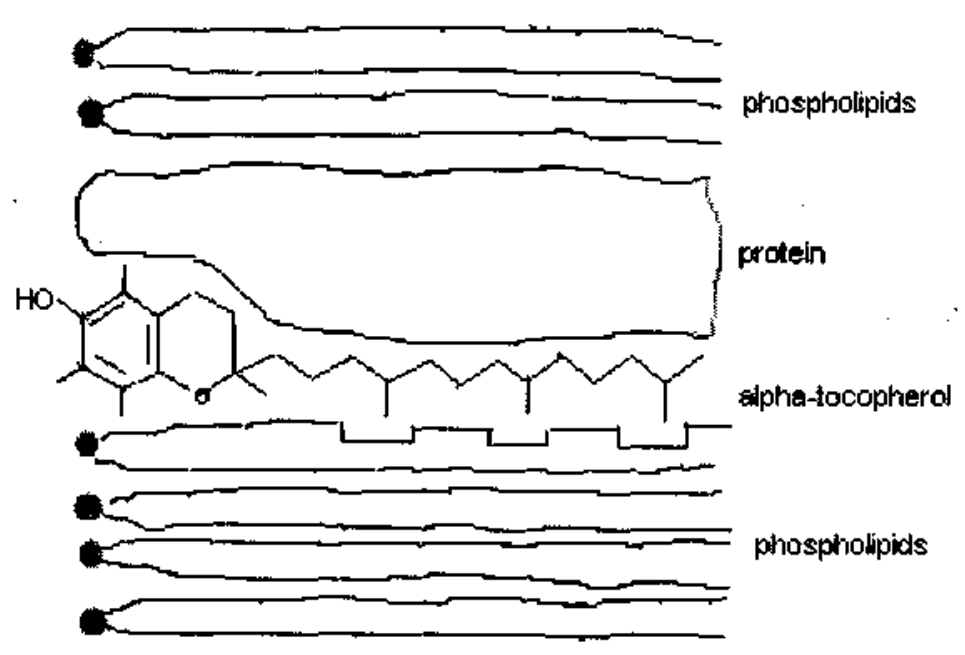

Figure 1 Diagrammatic Representation of the Proposed Interaction Between ccTocopherol and Polyunsaturated Phospholipids (68)

Lucy (71) studied the molecular interactions of synthetic phospholipid molecules with atocopherol and its derivatives in monolayers of phospholipids at the air/water interface, aTocopherol was found to exhibit the maximum interaction with polyunsaturated phospholipids 
and tocopherol penetration into the membrane was increased as unsaturation in the phospholipids was increased. It also appeared that a-tocopherol reduced the permeability to glucose and chromate ions when the liposomes were prepared from phospholipids containing arachidonic acid residues. Giasuddin and Diplock (83) studied the effect of adding specific unsaturated lipids on the growth and permeability of 2-deoxyglucose of isolated mouse fibroblasts. It was found that deoxyglucose transport and optimal growth depended on the presence of linoleic acid, cholesterol and vitamin E. Butylated hydroxytoluene an antioxidant, was unable to replace vitamin $\mathrm{E}$ which indicates that the activity of vitamin $\mathrm{E}$ does not depend upon its antioxidant properties alone. It depends on its lipid nature as well.

Proteins as well as lipids form an important constituent of cellular membranes. Therefore, membrane-bound proteins and enzymes may also be affected in vitamin E-deficiency. Mc Cay and King (84) proposed a scheme where NADPH-oxidase activity leads to a peroxidation attack on unsaturated membrane lipids in liver microsomes. They suggested that a-tocopherol must be localised in the membrane, close to NADPH oxidase which generates free radicals, so that the free radicals can be trapped. If vitamin $\mathrm{E}$ is important in maintaining the integrity of biological membranes against disruption by free radicals, other functions mediated through cell membranes such as enzymatic activities, ion transport, receptor availability etc. would be greatly affected $(85,86,87)$. A loss of enzymatic activities such as cytochrome P450, glucose-6phosphatase and UDP-glucuronyl transferase, catalase and fragmentation of lysosomal membranes with liberation of hydrolytic enzymes have been linked to lipid peroxidation (88, 89).

The ratio of PUFA to vitamin $\mathrm{E}$ in biological membranes was found to be compatible with the vitamin $\mathrm{E}$ chain-breaking antioxidant function. In mitochondrial membranes, the ratio of molecules of PUFA to molecules of a-tocopherol was 200 to 1 (90) whereas Kornbrust and Mavis (66) found a ratio of PUFA to vitamin E of 200/1 - 2000/1 in the microsomes of various rat tissues. The greatest concentrations of a-tocopherol was found in lisosomes and golgi membranes in the order of $1: 65$ phospholipid molecules (91).

The phospholipids in the red blood cell membrane contain a variety of fatty acids varying in chain length and in the number of double bonds. The physical characteristics of phospholipids are largely determined by their fatty acyl constituents. Alterations in fatty acyl groups can affect the shape and permeability (92). An increase in the degree of unsaturation of phospholipid fatty acids increases the lipid fluidity, whereas an increase in the SPH/PC ratio or in the cholesterol/phospholipid ratio decreases membrane fluidity (93).

Relatively large elevations in the dietary polyunsaturated/saturated fatty acid ratio have been shown to increase the requirement for vitamin $\mathrm{E}$ with respect to biological parameters (94, 95) and to influence the susceptibility of tissues to lipid peroxidation. Experiments with liposomes have shown that high lipid unsaturation results in increased lipid peroxidation (96, 97, 98). Studies performed with human erythrocytes showed a significant positive correlation between the relative concentrations of arachidonic acid $\left(\mathrm{C}_{2} \mathrm{O}_{4}\right)$ and lipid peroxidation (99). The 
results demonstrate that in red cells obtained from healthy persons only fatty acids with four or more double bonds are involved in membrane peroxidation reactions when exposed to peroxide stress. Arachidonic acid and docosahexanoic acid are the main substrates of the red cell mehmbrane peroxidation, whereas linoleic acid is of minor importance (99).

Diplock and Lucy (68) calculated the ratio of arachidonic acid residues to a-tocopherol to be about $500: 1$ in red blood cell membranes. This ratio is lower in mitochondrial membranes (90) when compared to microsomes of tissues (66) and red blood cell membranes (68). aTocopherol is more concentrated in the mitochondria than these two tissues (90).

\section{cc-Tocopherol as an antioxidant}

Our health is under constant attack from free radicals. Free radicals are highly reactive molecules produced by cellular (100-102) and environmental sources (103, 104). These unstable molecules attack healthy cells, weakening cell membranes and leading to cell damage and diseases $(105,106)$. Polyunsaturated fatty acids are very susceptible to attack by free radicals. Vitamin $\mathrm{E}$ is thought to prevent the spread of peroxidation initiated by free radicals through the fatty acids of phospholipids as a chain-breaking antioxidant (107-114).

Initiation of peroxidation of an unsaturated fatty acid (LH) is caused following attack by any chemical species (free radical e. g., a hydroxyl radical) that has sufficient reactivity to abstract a hydrogen atom from a methylene carbon in the side chain to form a fatty acyl radical (L) (1). The resulting carbon centered radical (L) can have several fates the most likely one is to undergo molecular rearrangement. This is followed by acceptance of oxygen (2) to give a fatty acid peroxy radical (LOO) (2).

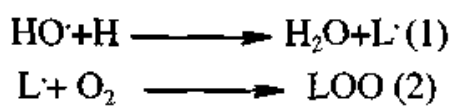

These peroxy radicals are very highly reactive themselves and easily set up a chain reaction. They require an additional $\mathrm{H}$ to become stable. This hydrogen may be donated from an adjacent fatty acid molecule ( $\left.\mathrm{LH}^{\prime}\right)$, forming another free radical $\left(\mathrm{L}^{\prime}\right)$ thereby setting up a chain reaction (3).

$$
\mathrm{LOO}^{\prime}+\mathrm{LH}^{\prime} \longrightarrow \mathrm{LOOH}^{\prime} \mathrm{L}^{\prime}
$$

The carbon atom most vulnerable to radical formation is the one between two cis double bonds ie $-\mathrm{CH}=\mathrm{CH}-\mathrm{CH} 2-\mathrm{CH}=\mathrm{CH}-$. Therefore oleic acid with only one cis double bond has no such carbon but any carbon atom adjacent to the double bond has vulnerability to some extent. Linoleic acid (Ci8:2) has one carbon atom between two double bonds and is much more vulnerable to radical formation, linolenic acid (Ci8:3) has two such carbon atoms and arachidonic acid (C20:4) has three. The chemistry of these compounds is such that linolenic acid is twice as vulnerable as linoleic acid and arachidonic acid is three times as vulnerable. 
Vitamin $\mathrm{E}$ and other phenolic antioxidants inhibit reaction 3 and are thus chain breaking antioxidants $(28,115-117)$. The effect of a-tocopherol stops this peroxidation spiral. The peroxy radical can be quenched by the $\mathrm{H}$ of phenolic $\mathrm{OH}$ group of oc-tocopherol (a-T) (3). The principle role of a-tocopherol is to scavenge the lipid peroxyl radical before it attacks the target lipid.

Two peroxyl radicals are trapped for every a-tocopherol molecule oxidized (118). Tocopherol itself becomes a relatively stable free radical (tocopheroxyl radical a-T) (50) that does not propagate the radical chain (fig .2).

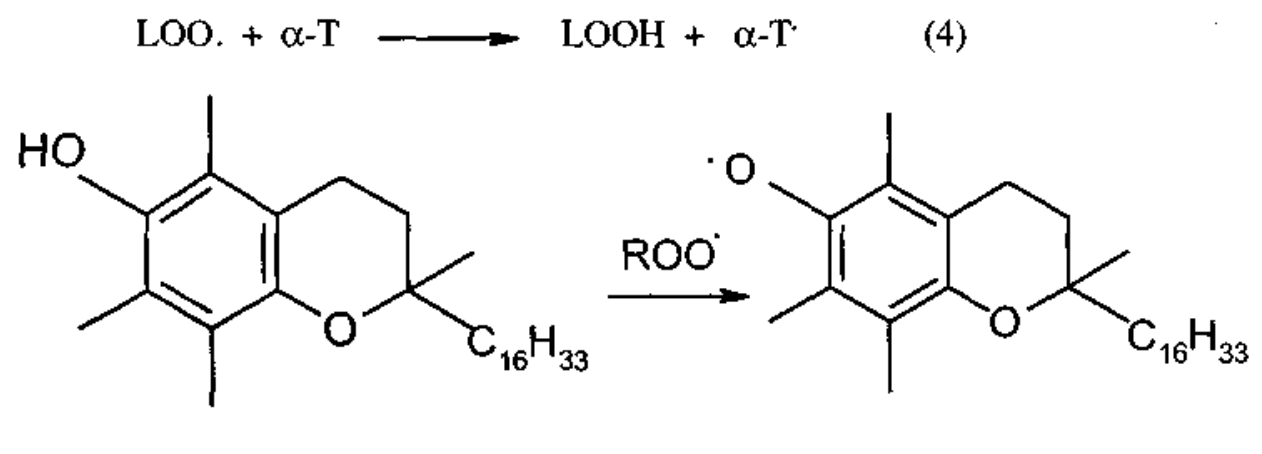

tocopheroxyl radical

Figure 2. Peroxyl trapping by a-tocopherol

Reaction of the tocopheroxyl radical with a peroxyl radical yields two groups of products $(119,120)$. The first group consists of 8 a-substituted tocopherons which either have a peroxylderived adduct or a hydroxyl group at C-8 a of the chromanol system. The 8 aalkyldioxytocopherons hydrolyse to 8 a-hydroxy tocopherons and then arranges to atocopherylquinone (fig. 3) (121). The second group consists of epoxy 8 ahydroperoxytocopherons which have an epoxide at either $\mathrm{C}-4 \mathrm{a} / \mathrm{C}-5$ or $\mathrm{C}-7 / \mathrm{C}-8$ of the chromanol system and a hydroperoxy substutient at C-8a which hydrolyse and rearrange to epoxyquinones (fig .3). a-Tocopherol is vulnerable to oxidation to minor products as dimers and trimers during peroxyl scavenging as well (120). 


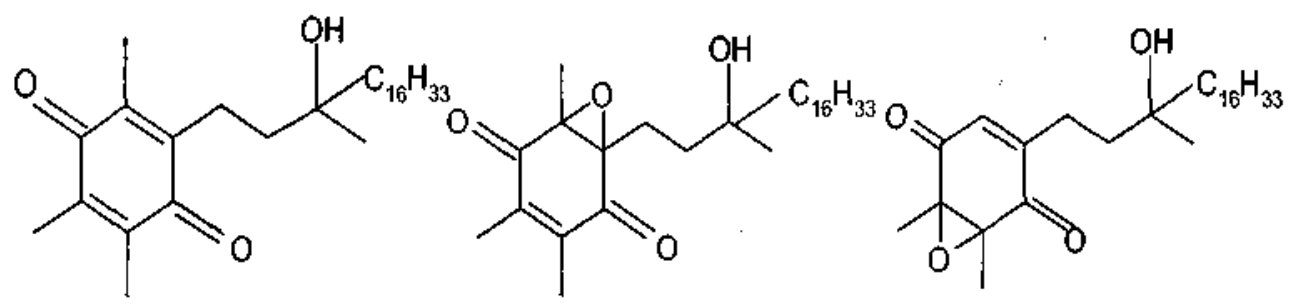

$\alpha$-Tocopherylquinone

Epoxyquinones

Figure 3. Oxidation products of a-Tocopherol by peroxyl radicals

Vitamin E reacts primarily with peroxyl radicals because of the following reasons:

1) Propagation is the slowest step (reaction 3) in lipid peroxidation and peroxyl radicals are much higher concentrations than other radicals involved (122).

2) Peroxyl radicals react with vitamin E more faster than other molecules (f.<?.adjacent polyunsaturated fatty acids) (50).

3) Vitamin $E$ is poor inhibitor of reactions 1 and 2 (123).

Tocopherols react with other reactive oxidants, including alkoxyl radicals $(124,125)$, singlet oxygen $(126,127)$, nitrogen dioxide (128), peroxinitrite (129), ozone (130) and superoxide (131). Reaction of a-tocopherol with other oxidant has been studied in several model systems. Although some of the products are identical to those produced by peroxyl radicals, some characteristic products are produced by individual oxidants $(131,125)$ Except for singlet oxygen a-tocopherol has relatively little kinetic advantage in scavenging these other oxidants. These oxidants may probably react directly with a-Tocopherol to a much smaller extent than do peroxyl radicals.

The antioxidant theory (69) was supported by the fact that several vitamin E-deficiency diseases of animals are prevented by antioxidants (132-135) and furthermore there is evidence of increased lipid peroxidation in tissues from deficient animals (136-138).

According to the antioxidant theory it should be possible to detect tocopherol metabolites, a-tocopherol can be converted to a-tocopheryl quinone in vivo and oxidation products of atocopherol were reported in some animals (139-141). However the quantity of cc-tocopheryl quinone detected in tissues is very small. Tappel has suggested that the tocopheroxy radicals formed from tocopherol by removal of the phenolic hydrogen can be reduced back to tocopherol by vitamin C (142). The antioxidant efficiency of vitamin $\mathrm{E}$ appears to be greatly enhanced by regeneration of the vitamin from its oxidised products (143). Appreciation of other antioxidants (144-146) has developed the notion that while vitamin E protects lipids other antioxidants must recycle vitamin E. The other major antioxidants are coenzyme Q and vitamin C $(147,148)$ Regeneration of a-tocopherol from its tocoperoxyl radical have been demonstrated by vitamin 
A (149) , C (150) and coenzyme Q (152) in vitro. However there is some doubt about the significance of regeneration by vitamins $\mathrm{A}$ and $\mathrm{C}$ in vivo.

Another explanation for the low levels of cc-TQ in tissues is that the tocopherol may be one of the last antioxidant substances to be consumed during oxidative stress. Burton and Ingold, found that other antioxidants such as sulphydryl groups in proteins were found to be used preferentially to tocopherols during oxidations initiated by free radicals in human plasma $(28,153)$. Indeed, a radical (tocopheroxy radical) reductase activity has been found by Packer $e t$ al, (154). Therefore the. tocopheroxy radical may be reduced to the native form of vitamin E by this enzyme.

\section{Requirements of vitamin $\mathrm{E}$}

At present estimations of ideal vitamin $\mathrm{E}$ intake and requirements are mainly based on its interaction with polyunsaturated fatty acids (PUFA). High intake of PUFA increases the requirement for vitamin $\mathrm{E}$. This is based on the data from animal and a few human studies (155). Food with high PUFA often contains high vitamin E but this is not always the case. Margarines and vegetable oils are relatively rich in y-tocopherol with $10 \%$ the biological activity of a-tocopherol (155). Therefore increasing PUFA in the diet will not always increase total vitamin E intake to maintain an ideal ratio of above $0.4 \mathrm{mg} \mathrm{d}$-cc-tocopherol/g PUFA.

In order to set the ideal intake of vitamin E several other factors should be considered. These include the physical activity, exposure to environmental pollutants, intake of total calories, percent energy from total fat and from PUFA, intake of vitamin $\mathrm{C}, \mid 3$-carotene and other antioxidants. High levels of vitamin $\mathrm{C}$ has been shown to decrease vitamin $\mathrm{E}$ requirements in the animal experiments and remains to be shown in human. Furthermore environmental pollutants, lifestyle, habits like smoking, exercise and alcohol may induce oxidative stress and increase antioxidant requirement.

The dietary reference intakes (DRIs) that is the latest recommended vitamin E requirements, were published in 2000 by the Food and Nutrition Board of the Institute of Medicine, National Academy of Sciences (156). These new DRIs were largely based on the studies by Horwitt at the Elgin State Hospital in the 1950s and 1960s (157-160). The recommended dietary allowance (RDA) for vitamin E, based on a long term study was $30 \mathrm{IU}$ in the 1968 edition but was decreased to 15 IU (155). The 1989 RDA was expressed in atocopherol equivalents, for which y-tocopherol was estimated to be equivalent to $1 / 10^{*}$ of the activity of cc-tocopherol (161). However 2000 DRI in contrast with 1989 RDA, indicates that only a-tocopherol can meet vitamin E requirements. The 2000 DRI was based on the observation that only a-tocopherol has a protein, a-tocopherol transfer protein (oc-TTP) that regulates plasma a-tocopherol concentrations. The studies with a-TTP indicates that oc-TTP binds a-tocopherol but has little affinity for y-tocopherol (162). Humans having a-TTP gene defect become deficient in vitamin E (162) as do mice (163). Moreover administration of a- 
tocopherol reverses human vitamin E deficiency sendroms providing evidence that humans require a-tocopherol. $y$-Tocopherol may have health benefits but these have not been shown in humans yet.

The basis for the 2000 dietary reference intake (DRI) for vitamin E is the health benefit of the vitamin for humans (156). The new DRI take into account not only the deficiency sendromes but also the amount of minerals and vitamins that provide an optimum benefit across the life span. The in vitro haemolysis test was used as a marker of vitamin E status due to the fact that erythrocytes become sensitive to peroxide-induced haemolysis in vitro and have a faster turnover rate in vivo in vitamin E deficiency with neurologic abnormalities (164). All of these were reversed by a-tocopherol supplements (156). Horwitt et al (157) also used haemolysis test to evaluate vitamin $\mathrm{E}$ status in humans who had vitamin $\mathrm{E}$ deficient diets for longer than 5 years and then were given vitamin E supplements. These data were used to set both the 1968 RDA (30 IU vitamin E) and the 2000 DRI (15 mg 2fl-a-tocopherol or $22 \mathrm{IU}$ /?/?i?-a-tocopherol) (natural) or $33 \mathrm{IU}$ a//-rac-oc-tocopherol (synthetic).

\section{CONCLUSION}

Vitamin E is lipid-soluble vitamin comprised of a family of 8 stereoisomers characterised by a chromanol ring with a phytyl side chain referred to as tocopherols and tocotrienols. octocopherol is a predominant isomer found in the body especially in membranes and the most potent.

The molecular mechanism of vitamin $\mathrm{E}$ which plays a role in a variety of physiological and biochemical functions is probably mediated either by the antioxidant function or its membrane stabilizing effect. It breaks peroxyl chain propagation reactions and is an efficient lipid peroxyl radical scavenger. Vitamin $\mathrm{E}$ is may be regenerated form its radical form by redox reactions involving coenzyme $\mathrm{Q}$, enhancing its role as a lipid antioxidant.

\section{REFERENCES}

1. Evans, H. M., Bishop, K. S. "On the existence of a hitherho unrecognised dietary factor essential for reproduction" Science 56, 650-651 (1922).

2. Pappenheimer, A. M., Goettsch,M. J. Exp. Med., 59,35 (1934).

3. Evans, H. M., Emerson, O. H., Emerson, G. A. /. Biol. Chem., 113, 319 (1936).

4. Emerson, O. H., Emerson, G. A., Mohammed, A., Evans, H. M. "The chemistry of vitamin E. Tocopherols from various sources" /. Biol. Chem., 122,99-107.

5. Diplock, A. T., Baum, H., Lucy, J. A. "The effect of vitamin E on the oxidation state of selenium in rat liver" Biochem J., 123, 721-732 (1971). 
6. Dam. H. "Interrelations between vitamin E and polyunsaturated fatty acids in animals" Vit. Horm., 20, 527-540 (1962).

7. Pennock, J. F.- Hemming, F. W., Kerr, J. D. "A reassessment of tocopherol chemistry"Bioc/iem. Biophys. Res. Commun., 17, 542-548 (1964).

8. Kamamleldin, A., Appelqvist, L. A. "The chemistry and antioxidant properties of tocopherols and tocotrienols" Lipids, 31,671-701 (1996).

9. Newton, R. P., Pennock, J. F. Phytochem., 10, 232 (1971).

10. Dilley, R. A., Crane, F. L. Plant. Physiol., 38,452 (1963).

11. Barr, R., Arntzen, C. J. Plant. Physiol., 44, 591 (1969).

12. Kasparek, S. in Vitamin E; A Comprehensive Treatise, Machlin, L. J. (Ed.), Marcell Dekker, New York 7-65 (1980).

13. Azzi. A., Stocker, A. "Vitamin E : non-antioxidant roles" Prog. Lipid. Res., 39, 232255 (2002).

14. Azzi, A., Breyer, I., Feher, M., Ricciarelli, R., Stocker, A., Zimmer, S., Zingg, J. "Nonantioxidant functions of alpha-tocopherol in smooth muscle cells" /. Nutr., 131, 378S-81S (2001).

15. Rimbach, G., Minihane, A. M., Majewicz, J., Fisher, A., Palluf, J., Virgli, F., Weinberg, P. D. "Regulation of cell signalling by vitamin E" Proc. Nutr. Soc, 61, 415-25 (2002).

16. Azzi, A., Ricciarelli, R., Zingg, J. M. "Non-antioxidant molecular functions of alphatocopherol (vitamin E)" FEBS Lett., 519, 8-10 (2002).

17. Okott, H.S., Emerson, O.H.J. Am. Chem.Soc, 59, 1008(1937).

18. Rose, C. S., Gyorgy, P. "Specifity of hemolytic reaction in vitamin E-deficient erythrocytes" Am. J. Physiol., 168,414-420 (1952).

19. Bunyan, J., Green, J., Edwin, E. E., Diplock, A. T. "Studies on vitamin E" Biochem. J., 75,460-467 (1960).

20. Kasparek, S. in Handbook of vitamins; Nutritional, Biochemical and Clinical Aspects, Machlin, L J. (Ed.), Marcell Dekker, New York 7-65 (1984).

21. Diplock, A. T., Xu, G-L., Yeow, C-L., Okiiola, M. "Relation of tocopherol structure to biological activity, tissue uptake and prostaglandin synthesis" Ann. N. Y. Acad. Sci., 570,72-84(1989).

22. Weiser, H., Vecchi, M. "Stereoisomers of alpha-tocopherylacetate: II: biopotencies of all eight stereoisomers, individually or in mixtures, as determined by rat resorptiongestation tests" Int. J. Vitami Nutr. Res., 52, 351-370 (1982). 
23. Cohn, W. "Bioavailability of vitamin E" Eur. J. Clin. Nutr., 51(Suppl 1), S80-S85 (1997).

24. Duthie, G. G., Gonzalez, B. M., Morrice, P. C, et al. "Inhibitory effects of isomers of tocopherols on lipid peroxidation of microsomes from vitamin-E-deficient rats" Free radio. Res. Commun., 15, 35-40 (1991).

25. Wolf, G., "Gamma-tocopherol: an efficient protector of lipids against nitric oxideinitiated peroxidative damage" Nutr. Rev., 55, 376- 378 (1997).

26. Liu, M., Wallin, R., Wallmon, A., Saldeen, T. "Mixed tocopherols have a stronger inhibitory effect on lipid peroxidation that a-tocopherol alone" J. Cardiovasc. Pharm., 39,714-721(2002).

27. Burton, G. W., Traber, M. G. "Vitamin E:antioxidant activity , biokinetics and bioavailability. Ann. Rev. Nutr., 10,357-382 (1990).

28. Burton, G. W., Ingold, K. U. "Vitamin E: application of the principles of physical organic chemistry to the exploration of its structure and function" Ace. Chem. Res., 19, 194-201 (1986).

29. Dillard, C. J., Gavino, V. C, Tappel, A. L. "Relative antioxidant effectiveness of octocopherol and y-tocopherol in iron-loaded rats" /. Nutr., 113, 2266-2273 (1983).

30. Weimann BJ, Weiser H. "Functions of vitamin E in reproduction and in prostacyclin and immunoglobulin synthesis in rats" Am. J. Clin. Nutr., 53,1056S-1060S (1991).

31. Burton G. W., Ingold, K. U. "Autooxidation of biological molecules. 1.The antioxidant activity of vitamin $\mathrm{E}$ and related chain-breaking phenolic antioxidants in vitro" J. Am. ChemSoc., 103, 6472-6477 (1981 a).

32. Pokorny, J. "Major factors affecting the autoxidation of lipids' in Autoxidation of unsaturated Lipids" Chan, H. W. S. (Ed.) Academic Press, London, 141-206 (1987).

33. Olcott, H. S., Van Der Ven, J. "Comparison of antioxidant activities of tocol and its methyl derivatives" Lipids, 3, 331-334 (1968).

34. Parkhurst, R. M., Skinner, W. A., Strum, P. A. "The effect of various concentrations of tocopherols and tocopherol mixtures on the oxidative stabilities of a sample of lard" I. Am. Oil. Chem. Soc., 45, 641-642 (1968).

35. Chow, C. K., Draper, H. H. "Oxidative stability and activity of the tocopherols in corn and soybean oils" Int. J. Vit. Nutr. Res., 44, 396-403 (1974).

36. Koskas, J. P., Cillard, J., Cillard, P. "Autooxidation of linoleic acid and behavior of its hydroperoxides with and without tocopherols" J. Am. Oil Chem. Soc., 61, 1466-1469 (1984). 
37. Esterbauer, H., Striegl, G., Ppuhl, H., Oberreither, S., Rotheender, M., El-Saadani, M., Jurgens, G. "The role of vitamin E and carotenoids in preventing the oxidation of low-density lipoproteins" Ann. N. Y. Acad. Sci., 570, 254-267 (1989).

38. Gottstein, T., Grosch, W. "Model study of different antioxidant properties of a- and ytocopherol in fats" Fat Sci. Technol., 92, 139- 144 (1990).

39. Timmermann, von F. "Tocopherole-antioxidative Wirkun bei Fetten Olen" Fat Sci. \& Technol., 92, 201-206 (1990).

40. Jung, M. Y., Min, D. B. "Effects of a-, y- and 5-tocopherols on oxidative stability of soybean oil" J. Food Sci., 55, 1464-1465 (1990).

41. Jung, M. Y., Min, D. B. "Effects of a-, y- and 8-tocopherols on oxidative stability of purified soybean oil" Food Chem., 45,183-187 (1990).

42. Lea, C. H. "On the antioxidant activities of the tocopherols. II. Influence of substrate, temperature and level of oxidation" J. Sci. FoodAgric, 11, 212-218 (1960).

43. Nawar, W. W. Lipids in Food Chemistry, 2 nd ed. Fennema, O. R. (Ed.), Marcell Dekker, New York, 139-244 (1985).

44. Cillard, J., Cillard, P., Cormier, M., Girre, L. "a-Tocopherol prooxidant effect in aqueous media: Increased autooxidation rate of linoleic acid" /. Am. Oil Chem. Soc, 57,252-255(1980).

45. Lea, C. H. "Antioxidants in dry fat systems. I. Influence of the fatty acid composition of the substrate" /. Sci. FoodAgric, 11, 143-150 (1960).

46. Frankel, E. N. "The antioxidant and nutritional effects of tocopherols, ascorbic acid and P-carotene in relation to processing of edible oils" in Nutritional Impacts of Food Processing,

47. Niki, E., Kawakami, A., Saito, M., Yamamoyo, Y., Tsuchiya, J. "Effect of phytyl side chain of vitamin E on its antioxidant activity" /. Biol. Chem., 260, 2191-2196 (1985).

48. Molennaar, L, Hulstert, C. E., Hardonk, M. J. "Role in function and ultrastructure of cell membrane" in Vitamin E: A Comprehensive Treatise, Marcel Dekker, Inc. New York, Machlin L. J. (ed.), p. 372-389 (1980).

49. Urano, S., Matsuo, M. "Membrane stabilizing effect of vitamin E. Ann. N. Y. Acad. Sci., 570,524-526 (1989).

50. Burton G. W., Ingold, K. U. "Autoxidation of biological molecules. 1. The antioxidant activity of vitamin $\mathrm{E}$ and related chain- breaking phenolic antioxidants in vitro" J. Am. Chem. Soc, 103, 6472-6477 (1981). 
51. Niki, E., Tsuchiya, Y., Yoshikawa, Y., Yamamoto, Y., Kamiya, Y. "Oxidation of lipids. XIII. Antioxidant activities of _-, _-, gamma-, and delta- tocopherols" Bull. Chem. Soc. Jpn., 59,497-459 (1986).

52. Bunyan, J., Green, J., Edwin, E. E., Diplock, A. T. Studies on vitamin E. Biochem. J. 75,460-467(1960).

53. Fitch, C. D., Diehl, J. F. Proc. Soc. Exp. Biol. Med., 119, 553 (1965).

54. Leth, T., Sondergaard, H. "Biological activity of vitamin E compounds and natural materials by the resorption-gestation test, and chemical determination of the vitamin $\mathrm{E}$ activity in foods and feeds" JNutr., 107,2236-2243 (1977).

55. Machlin, L. J., in handbook of Vitamins, Nutritional, Biochemical and Clinical Aspects, Machlin L. J (ed.), Marcel Dekker, New York, p. 99 (1984).

56. Yoshida, Y., Niki, E., Noguchi, N. "Comparative study on the action of tocopherols and tocotrienols as antioxidant: chemical and physical effects" Chem. Phys. Lipids, 123, 63-75 (2003).

57. Erin, A. N., Spirin, M. M., Tabidze, L. V., Kagan, V. E. "Formation of cc-tocopherol complexes with fatty acids. A hypothetical mechanism of stabilization of biomembranes by vitamin E" BBA., 11A, 96-102 (1984).

58. Jain, S. K. "Vitamin E and stabilization of membrane lipid organization in red blood cells with peroxidative damage" Biomed. Biochim. Acta 42,43-47 (1983).

59. Lucy, J. A. "Vitamin E and oxygen: studies relevant to the action of vitamin E in membranes" Biochem J., 99,57-69 (1966).

60. Silber, R., Winter, R., Kayden, H. J. "Tocopherol transport in the rat erythrocyte" /. Clin. Invest,. 48,2089-2095 (1969).

61. Shinozaki, K., Takeda, H., Innazu, M., Matsumiya, T., Takasaki, M. "Abnormal incorporation and utilization of alpha-tocopherol in erythrocyte membranes of streptozotocin-induced diabetic rats" Eur. J. Pharmacol., 456,133-9 (2002).

62. Young, S. P., Johnson, A. W., Muller, D. P. "Effects of phytanic acid on the vitamin E status, lipid composition and physical properties of retinal cell membranes: implications for adult Refsum disease" Clin. Sci. (Lond)., 101,697-705 (2001).

63. Chow, C. K. "Distribution of tocopherol in human plasma and red blood cells" Am. J. Clin. Nutr., 28,756-761 (1975).

64. Chow, C. K. "Vitamin E in plasma, erythrocytes and erythrocyte membranes" Prog. Clin. Biol. Res., 292,445-451 (1989).

65. Gallo Torres., in Vitamin E, a Comprehensive Treatise, Machlin, L. J. (ed.), Marcel Dekker, New York, p. 193 (1980). 
66. Kornbrust, D. J., Mavis, R. D. "Relative susceptibility of microsomes from lung, heart, liver, kidney, brain and testes to lipid peroxidation: correlation with vitamin $\mathrm{E}$ content" Lipids, 15, 315-22 (1980).

67. Surai, P. F., Sparks, N. H. "Tissue-specific fatty acid and alpha-tocopherol profiles in male chickens depending on dietary tuna oil and vitamin E provision" Poult Sci., 79, 1132-42 (2000).

68. Diplock, A. T., Lucy, J. A. "The biochemical modes of action of vitamin E and selenium: a hypothesis" Febs. Lett., 29,205-210 (1973).

69. Burton, G. W., Ingold, K. U. "Beta-Carotene: an unusual type of lipid antioxidant" Science, 224,569-73 (1984).

70. Tappel, A. L. "Vitamin E as the biological lipid antioxidant" Vitam. Horm., 20, 493503 (1962).

71. Lucy, J. A. "Functional and structural aspects of biological membranes: a suggested structural role of vitamin E in the control of membrane permeability and stability" Ann. N. Y.Acad. Sci., 203, 3-16 (1972).

72. Ulusu, N. N, Sahilli, M., Avci A, Canbolat, O., Ozansoy, G., Ari, N., Bali, M., Stefek, M., Stole, S., Gajdosik, A., Karasu, C. "Pentose phosphate pathway, glutathionedependent enzymes and antioxidant defense during oxidative stress in diabetic rodent brain and peripheral organs: effects of stobadine and vitamin E" Neurochem. Res., 28, 815-823 (2003).

73. Molenaar, I., Vos, J., Jager, F. C, Hommes, F. A. "The influence of vitamin E deficiency on biological membranes. An ultrastructural study on the intestinal epithelial cells of ducklings" Nutr. Metab., 12, 358-70 (1970).

74. Yamashita K, Kagaya M, Higuti N, Kiso Y. "Sesamin and alpha-tocopherol synergistically suppress lipid-peroxide in rats fed a high docosahexaenoic acid diet" Biofactors, 11, 11-3 (2000).

75. Barclay, R. L. C., Ingold, K. U. "Autoxidation of biological molecules. II. The autoxidation of a model membrane. A comparison of the autoxidation of egg lecithine phosphatidylcholine in water and chlorobenzene" /. Am. Chem. Soc, 103, 6472-6477 (1981).

76. Arai H, Uchida K, Fukunaga K, Nagasaka Y, Mohri S, Furumoto H, Kuramitsu Y, Nakamura K. "Effect of alpha-tocopherol on the oxidative modification of apolipoprotein E in human very-low-density lipoprotein" Biosci Biotechnol Biochem., 67,402-5(2003).

77. Kagan, V. E. "Tocopherol stabilizes membrane against phospholipase A, free fatty acids and phospholipids" Ann. N. Y. Acad. Sci., 570, 121- 135 (1989). 
78. Grams, Y. W., Eskins, K. "Dye-sensitized photoperoxidation of tocopherols. Correlation between singlet oxygen reactivity and vitamin E activity" Biochem., 11, 606-610(1972).

79. Newkirk,J.J.,Waite,M.fift4.,225,224 (1971).

80. Erin, A. N., Gorbunov, N. V., Brusovanik, V. I., Tyurin, V. A., Prilipko, L. L. "Stabilization of synaptic membranes by ct-tocopherol against the damaging action of phospholipases. Possible mechanism of biological action of vitamin E" Brain Res., 398, 54-80 (1986).

81. Kagan, V. E., Arkhipenko, Yu. V., Dobrina, S. K., Kozlov, Yu. P., Ritov, V. B. "Stabilizing effects of vitamin E on biomembranes exposed to lipid peroxidation" Biochemistry USSR., 42, 1194-1199 (1977).

82. Mukherjee AK, Ghosal SK, Maity CR. "Lysosomal membrane stabilization by alphatocopherol against the damaging action of Vipera russelli venom phospholipase A2" Cell Mol Life Sc, 53, 152-5 (1997).

83. Giasuddin, A. M., Diplock, A. T. "The influence of vitamin E and selenium on the growth and plasma membrane permeability of mouse fibroblasts in culture" Arch. Biochem. Biophys., 196,270-280 (1979).

84. Mc Cay, P., King, M. M., in Vitamin E, a Comprehensive Treatise, Machlin, L. J. (ed.), Marcel Dekker, New York, p. 289 (1980).

85. Divakaran, P., Wiggins, R. C. "Tocopherol in brain metabolism and disease: a review" Metab. Brain. Dis., 2, 1-16 (1987).

86. Verstraeten, S. V., Keen, C. L., Schmitz, H. H., Fraga, C. G., Oteiza, P. I. "Flavan3-ols and procyanidins protect liposomes against lipid oxidation and disruption of the bilayerstructure" Free radic. Biol. Med., 34, 84-92 (2003).

87. Spickett, C. M., Jerlich, A., Panasenko, O. M., Arnhold, J., Pitt, A. R., Stelmaszynska, T., Schaur, R. J. "The reactions of hypochlorous acid, the reactive oxygen species produced by myeloperoxidase, with lipids" Acta Biochim. Pol., 47, 889899 (2000).

88. Hogberg, J., Bergstrand, A., Jacobsson, S. V. "Lipid peroxidation of rat-liver microsomes. Its effect on the microsomal membrane and some membrane-bound microsomal enzymes" Eur J Biochem., 37, 51-9 (1973).

89. Younes, M., Albrecht, M., Siegers, C.P. "Interrelation between lipid peroxidation and lysosomal enzyme release in the presence of carbon tetrachloride, cumene hydroperoxide or thioacetamide" Res Commun Chem Pathol Pharmacol., 40, 121-32 (1983).

90. Gruger, E. H. Jr., Tappel, A. L. "Reactions of biological antioxidants. 3. Composition of biological membranes" Lipids, 6,147-8 (1971). 
91. Buttriss, J. L., Diplock, A. T. "The alpha-tocopherol and phospholipid fatty acid content of rat liver subcellular membranes in vitamin E and selenium deficiency" Biochim Biophys Acta.; 963, 61-9 (1988).

92. Kuypers FA, Easton EW, van den Hoven R, Wensing T, Roelofsen B, op den Kamp JA, van Deenen LL. "Survival of rabbit and horse erythrocytes in vivo after changing the fatty acyl composition of their phosphatidylcholine" Biochim Biophys Acta., 819, 170-8 (1985).

93. Cooper R. A. "Abnormalities of cell-membrane fluidity in the pathogenesis of disease" NEnglJMed., 297,371-7 (1977).

94. Jager, F. C. "Linoleic acid intake and vitamin E requirement in rats and ducklings" Ann. N. YAcad. Sci., 203,199-211 (1972).

95. Hendriks WH, Wu YB, Shields RG, Newcomb M, Rutherfurd KJ, Belay T, Wilson J. "Vitamin E requirement of adult cats increases slightly with high dietary intake of polyunsaturated fatty acids" JNutr., 132(6 Suppl 2):1613S-5S (2002).

96. Herrero A, Portero-Otin M, Bellmunt MJ, Pamplona R, Barja G. "Effect of the degree of fatty acid unsaturation of rat heart mitochondria on their rates of $\mathrm{H}_{2} \mathrm{O}_{2}$ production and lipid and protein oxidative damage" Mech Ageing Dev.; 122, 427-43 (2001).

97. Mowri, H., Nojima,S., Inoue, K. "Effect of lipid composition of liposomes on their sensitivity to peroxidation" J Biochem. (Tokyo), 95, 551-8 (1984).

98. Clemens MR, Ruess M, Bursa Z, Waller HD. "The relationship between lipid composition of red blood cells and their susceptibility to lipid peroxidation" Free Radic. Res. Commun., 3,265-71 (1987).

99. Hong, M. Y., Chapkin, R. S., Barhoumi, R., Burghardt, R. C, Turner, N. D., Henderson, C.E, Sanders, L. M., Fan, Y. Y., Spinka, C. M., Carroll, R. J., Lupton, J. R. "Fish oil increases mitochondrial phospholipid unsaturation, upregulating reactive oxygen species and apoptosis in rat colonocytes" Carcinogenesis, 23, 1919-1925 (2002).

100. Lenaz, G. "The mitochondrial production of reactive oxygen species: mechanisms and implications in human pathology" IUMBMLife, 52, 159-164 (2001).

101. Babior, B. M. "The respiratory burst of phagocytes" /. Clin. Invest., 73, 559-601 (1984).

102. Ramasarma, T. "Generation of $\mathrm{H}_{2} \mathrm{O}_{2}$ in biomembranes" Biochim. Biophys, Acta., 694, 69-83 (1982).

103. Zhou, J. F., Cai, D., Tong, G. Z. "Oxidative stress and potential free radical damage associated with photocopying. A role for ozone? " Free. Radic. Res., 37, 137-43 (2003). 
104. Bonura, T., Town, C. D., Smith, K. E., Kaplan, A. S. "The influence of oxygen on the yield of DNA double strand breaks in X-irradiated E. ColV Rad. Res., 63, 567-572 (1975).

105. Beckman, R., Flohe, L. "The pathogenic role of superoxide radicals in inflammation:efficacy of exogenous suporoxide dismutase" Bull. Eur. Physiopathol. Respir., 17(Suppl), 275-285 (1981).

106. Halliwell B. "Role of free radicals in the neurodegenerative diseases: therapeutic implications for antioxidant treatment"Z>Mgs' Aging, 18,685-716 (2001).

107. Gavazza, A., Catala, A.'The effect of alpha-tocopherol on the lipid peroxidation of mitochondria and microsomes obtained from rat liver and testis" Mol. Cell. Biochem., 225,121-8 (2001).

108. Witting, L. A. "Vitamin E and lipid antioxidants in free radical-initiated reactions" in Free Radicals in Biology, Pryor, W. A. (Ed.) 4, 295-327 (1980).

109. Van Gossum, A., Kurian, R., Whitwell, J., Jeejeebhoy, K. N. "Decrease in lipid peroxidation measured by breath pentane output in normals after oral supplementation with vitamin E" Clin. Nutr.,, 7, 53-57 (1988).

110. Takahashi, M., Tsuchiya, J., Niki, E. "Mode of action of vitamin E as antioxidant in the membranes as studied by spin labelling. Ann. N. Y. Acad. Sci., 57, 521-523 (1989).

111. O'Donnell, V. B., Chumley, P. H., Hogg, N., Bloodsworth, A., Darley-Usmar, V. M., Freeman, B. A. "Nitric oxide inhibition of lipid peroxidation: kinetics of reaction with lipid peroxyl radicals and comparison with _-tocopherol" Biochem., 36, 15216-15223 (1997).

112. Dillard, C. J., Dumelin, E. E., Tappel, A. L. "Effect of vitamin E on expiration of pentane and ethane by the rat" Lipids, 12, 109- 114 (1977).

113. Liebler, D. C, Kling, D.S., Reed, D. J. "Antioxidant protection of phospholipids bilayers by _-tocopherol" /. Biol. Chem., 261, 12114-12119 (1986).

114. Pedrielli, P., Skibsted, L. H. "Antioxidant and regeneration effect of quercetin, (-)epicatechin, and (+)-catechin on alpha-tocopherol in homogeneous solutions of peroxidating methyl linoleate" J Agric Food Chem., 50,7138-44 (2002).

115. Howard, J. A., Ingold, K. U. "Absolute rate constants for hydrocarbon autoxidation. VI. Alkyl aromatic and olefinic hydrocarbons" Can. J. Chem., 45, 793-801 (1967).

116. Bulger, E. M., Maier, R. V. "An argument for vitamin E supplementation in the management of systemic inflammatory response syndrome" Schock, 19, 99-103 (2003).

117. Behl, C, Moosman, B. "oxidative nerve cell death in Alzheimer's disease and stroke antioxidants as neuroprotective compounds" Biol. Chem., 383, 521-536 (2002). 
118. Howard, J. A. "Homogenous liquid phase autoxidations" in Free Radicals, Kochi, J.A. (Ed.), Wiley, New York, 3 (1973).

119. Liebler, D. C, Baker, P. F., Kaysen, K. L. "Oxidation of vitamin E.evidence for competing autoxidation and peroxyl radical trapping reactions of the tocopheroxyl radical" J.Am. Chem. Soc, 112,6995-7000 (1990).

120. Liebler, D. C, Burr, J. A. "Oxidation of vitamin E during iron-catalyzed lipid peroxidation: evidence for electron-transfer reactions of the tocopheroxyl radical" Biochemistry, 31, 8278- 8284 (1992).

121. Liebler, D. C, Kaysen, K. L. Kennedy, T. A. "Redox cycles of vitamin E: hydrolysis and ascorbic acid dependent reduction of 8 a-(alkyldioxy)tocopherons" Biochemistry, 28,9772-9777(1989)

122. Pryor, W. A. "Free radicals in autoxidation and aging in Free Radicals" in Molecular Biology, Aging, and Disease, Armstrong, D., Sohal, R. S., Cutler, R. G., Slater, T. F. (Eds.), Raven Press, New York, 13 (1984).

123. Czapski, G. "Reaction of OH" Methods. Enzymol., 105, 209-215 (1984).

124. Hopia A, Huang, S. W., Frankel, E. N. Effect of a-tocopherol and trolox on the decomposition of meyhllinoleatehydroperoxides. Lipids,. 31, 357-65 (1996).

125. Suarna, C., Baca, M., Southwell-Keely P. T. "Oxidation of the a-tocopherol model compound 2,2,6,7,8-pentamethyl-6-chromanol in the presence of alcohols" Lipids, 27, 447-453 (1992).

126. Clough, R. L., Yee, B. G., Foote, C. S. "Chemistry of singlet oxygen. XXX. The unstable primary product of tocopherol photooxidation. J. Am. Chem. Soc, 101, 683-686 (1979).

127. Kaiser, S., Di Mascio, P., Murphy, M. E., Sies, H. "Physical and chemical scavenging of singlet molecule oxygen by tocopherols" Arch. Biochem. Biophys., 211, 101-108 (1990).

128. Cooney, R. V., Harwood, P. J., Franke, A. A., Narala, K., Sumdstrom, A. K., Berggren, P. O., Mordan,, L. J. "Products of gamma-tocopherol reaction with $\mathrm{NO}_{z}$ and their formation in rat insulinoma (RINm5F) cells" Free Radic Biol Med., 19, 25969(1995).

129. Hogg, N., Joseph, J., Kalyanaraman, B. "The oxidation of alpha-tocopherol and trolox by peroxynitrite" Arch Biochem Biophys., 14, 153-8 (1994).

130. Liebler, D: C., Matsumoto, S., Litaka, Y., Matsuo, M. "Reactions of vitamin E and its model compound 2,2,5,7,8-pentamethylchroman-6-ol with ozone" Chem Res Toxicol., 6,69-74 (1993). 
131. Csallany, A. S., Ha, Y. L. "oc-Tocopherol oxidation mediated by superoxide anion. I. Reactions in aprotic and protic conditions" Lipids, 27, 195-200 (1992).

132. Ramirea-Tortosa, C, Andersen, O. M., Gardner, P. T., Morrice, P. C, Wood, S. G., Duthie, S. J., Collins, A. R., Duthie, G. G. "Anthocyanin-rich extract decreases indices of lipid peroxidation and DNA damage in vitamin E-depleted rats" Free Radic. Biol. Med., 31,1033-7 (2001).

133. Burczynski, J. M., Southard, S. J., Hayers, J. R., Longhurst, P. A., Colby, H. D. "Changes in mitochondrial and microsomal lipid peroxidation and fatty acid profiles in adrenal glands, testes, and livers from alpha-tocopherol-deficient rats" Free Radic. Biol. Med., 30,1029-35 (2001).

134. Gonca, S., Grattagliano, I., Altomare, E. "Protective effects of vitamin E and selenium on the renal morphology in rats fed high-cholesterol diets" Pathobiology, 68, 258-63 (2000).

135. Vendemiale. G., Grattagliano, I., Altomare, E. "An update on the role of free radicals and antioxidant defense in human disease" Int. J. Clin. Lab. Res., 29,49-55 (1999).

136. Cordeiro, M. B., Coimbra, T. M., Costa, R. S., Meirelles, M. S., Jordao, A. A. Jr., Vannucchi, H. "Lipid peroxidation in vitamin E-deficient rats submitted to subtotal nephrectomy" Ren. Fail. Jul, 2A, 407-19. ( 2002).

137. Maggi-Capeyron, M. F., Cases, J., Badia, E., Cristol, J. P., Rouanet, J. M., Besancon, P., Leger, C. L., Descomps, B. "A diet high in cholesterol and deficient in vitamin $\mathrm{E}$ induces lipid peroxidation but does not enhance antioxidant enzyme expression in rat liver" /. Nutr. Biochem., 13, 296-301 (2002).

138. Combs, G. F. "Assessment of vitamin E status in animals and man" Proc Nutr Soc, 40,187-94(1981).

139. Terentis, A. C, Thomas, S. R, Burr J. A, Liebler, D. C, Stocker, R. "Vitamin E oxidation in human atherosclerotic lesions" Circ. Res., 90, 333-9 (2002).

140. Yanagawa, K., Takeda, H., Matsumiya, T., Takasaki, M. "Age-related change in the alpha-tocopherolquinone/alpha-tocopherol ratio in the rat erythrocyte membrane "Nippon Ronen Igakkai Zasshi., 36, 335-41 (1999).

141. Weber, F., Wiss, O. "Reciprocal action between vitamin E and other food constituents".Bibl Nutr Dieta., 8,54-63 (1966).

142. Tappel, A. L. "Will antioxidant nutrients slow aging processes? " Geriatrics, 23, 97 105 (1968).

143. Kagan. V. E., Kuzmenko, A. I., Shvedova, A. A., Kisin, E. R., Li, R., Martin, I., Quinn, P. J., Tyurin, V. A., Tyurina, Y. Y., Yalowich, J. C. "Direct evidence for recycling of myeloperoxidase-catalyzed phenoxyl radicals of a vitamin $\mathrm{E}$ analogue, 
2,2,5,7,8- pentamethyl-6-hydoxy chromane, by ascorbate/dihydrolipoate in living HL-60 cells" Biochim. Biophysics. Acta., 1620,72-84 (2003).

144. Kiely, M., Morrissey, P. A., Cogan, P. F., Kearney, P. J. "Low molecular weight plasma antioxidants and lipid peroxidation in maternal and cord blood" Eur. J. Clin. Ator., 22, 861-864 (1999).

145. Quasim, T., McMillan, D. C, Talwar, D., Sattar, N., O'Reilly, D. S., Kinsella, J. "Lower concentrations of carotenoids in the critically ill patient are related to a systemic inflammatory" J. Clin. Nutr., 22,459-462 (2003).

146. Roberts, W. G., Gordon, M. H., Walker, A. F. "Effects of enhanced consumption of fruit and vegetables on plasma antioxidant status and oxidative resistance of LDL in smokerssupplemented with fish oil" Eur. J. Clin. Nutr., 57, 1303-1310 (2003).

147. Thomas, S. R., Neuzil. J., Mohr, D. "Coantioxidants make alpha-tocopherol an efficient antioxidant for low-density lipoprotein. Am. J. Clin. Nutr., 62, 1357S-1364S (1995).

148. Stoyanovsky, D. A., Goldman, R., Darrow, R. M., organisciak, D. T., Kagan, V. E. "Endogenous ascorbate regenerates vitamin $\mathrm{E}$ in the retina directly and in combination with exogenous dihydrolipoic acid" Curr. Eye Res., 14,181-189 (1995).

149. Bohm, F., Edge, R., McGarvey, D. J., Truscot, T. G. "Beta-carotene with vitamins E and C offers synergistic cell protection against NOx" FEBS Lett., 436,387-9 (1998).

150. Ho, C. T., Chan, A. C. "Regeneration of vitamin E in rat polymorphonuclear leucocytes" FEBS Lett., 306,269-270 (1992).

151. Tantcheva, L. P., Stoeva, E. S., Galabov, A. S., Braykova, A. A., Savov, V. M., Mileya, M. M. "Effects of vitamin E and vitamin C combination on experimental influenza virus infection" Methods Find. Exp. Clin. Pharmacol., 25, 259-264 (2003).

152. Ingold, K. U., Bowry, V. W., Stocker, R., Walling, C. "Autoxidation of lipids and antioxidation by alpha-tocopherol and ubiquinol in homogeneous solution and in aqueous dispersions of lipids: unrecognized consequences of lipid particle size as exemplified by oxidation of human low density lipoprotein" Proc. Natl. Acad .Sci, U S A., 90,45-9 (1993).

153. Jishage, K., Arita, M., Igarrashi, K. et al. "Alpha-tocopherol protein is important for the normal development of placental labyrinthine trophoblasts in mice" J. Biol. Chem., 273, 1669-1672 (2001).

154. Packer, L, Maguire, J., Melhorn, R., Serbinova, E., Kagan, V. "Mitochondria and microsomal membranes have a free radical reductase activity that prevents chromanoxyl radical accumulation" Biochem. Biophysics. Res. Commun., 159,229-235 (1989). 
155. Horwitt, M. K. "Interpretations of requirements for thiamine, riboflavin, niaci-triptofan and vitamin E plus comments on balance studies and vitamin $\mathrm{B}_{6}$ " Am. J. Clin. Nutr., 44, 973-985 (1986).

156. Food and Nutrition Board, Institute of Medicine. "Dietary reference intakes for vitamin C, vitamin E, selenium and carotenoids" Washington DC, National Academy Press (2000).

157. Horwitt, M. K., Harvey, C. C, Duncan, G. D., Wilson, W. C. "Effects of limited tocopherol intake in man with relationships to erythrocyte haemolysis and lipid oxidations" Am. J. Clin. Nutr., 4,408-419 (1956).

158. Horwitt, M. K., "Vitamin E and lipid metabolism in man" Am. J. Clin. Nutr., 8, 451461 (1960).

159. Horwitt, M. K. "Interrelationships between vitamin E and polyunsaturated fatty acids in adult men" Vitam. Horm., 20, 541-558 (1962).

160. Horwitt, M. K., Century, B., Zeman, A. A. "Erythrocyte survival time and reticulocyte levels after tocopherol depletion in man" Am. J. Clin. Nutr., 12, 99-106 (1963).

161. National Research Council. "Recommanded dietary allowances" $10^{\text {th }}$ ed. Washington, DC: National Academy of Sciences, (1989).

162. Hosomi, A., Arita, M., Sato, Y. et al. "Afinity for alpha-tocopherol transfer protein as a determinant of the biological activities of vitamin E analogs" FEBS Lett., 409, 105108 (1997).

163. Cavalier, I., Ouachi, K., Kayden, H. J. et al. "Ataxi with isolated vitamin E deficiency: heterogenity of mutations and phoenootypic variability in a large number of families" Am. J. Hum. Genet., 62, 301-310 (1998).

164. Farrell, P. M., Bieri, J. G., Fratantoni, J. F., Wood, R. E., di sant'Agnese, P. A. "The occureance and effects of human vitamin E efficiency. A study in patients with cystic fibrosis" /. Clin. Invest., 60, 233-241 (1977). 